\title{
Education in Human Development
}

\author{
Khadizhat Khadzhalova ${ }^{1},{ }^{*}$ Sabina Savzikhanova ${ }^{2}$, Nigara Eminova ${ }^{2}$ \\ ${ }^{1}$ Institute for Socio-Economic Research Dagestan Federal Research Centre of the Russian Academy of Sciences, \\ Russia \\ ${ }^{2}$ Dagestan State University of National Economy, Russia \\ *Email: chaha@mail.ru
}

\begin{abstract}
The article highlights the importance of human development, which is the main factor in developing society, economy and the state. Human development's main strategic directions are education, health care, the labour market, and other areas. Education is a crucial component of human development. In this regard, the purpose of this study is to identify the necessary conditions for the development and growth of educational potential, increase the level of efficiency of its use and ensure on this basis appropriate socio-economic growth.

The study analyses the situation in developing the educational sphere on the North Caucasus Federal District's example for 1990-2019. The main problems in the modern system of preschool, school and university education are identified. The role of state policy in education development is outlined, namely, in increasing the availability of its quality, which meets the requirements of innovative development of the economy, modern needs of society and every citizen.
\end{abstract}

Keywords: Human potential, Human development, Education, Educational potential, Human development index, North Caucasian Federal District.

\section{INTRODUCTION}

The transition of Russia to a new innovative sociallyoriented stage of development is associated with fundamental changes that occurred in the world at the turn of the 20-21st centuries, the main of which was the transformation of human potential into the main factor in the development of society, economy, and state [1]. Human potential becomes a fundamental category that defines the main goals, objectives, principles, priorities and strategic directions of state policy development.

The relevance of studying the problem of human potential is determined, first of all, by strategic documents of the state level in the field of human development [2]. Speaking at an extended meeting of the State Council of the Russian Federation with a report "On the Development Strategy of Russia until 2020", President of the Russian Federation V.V. Putin noted that "the transition to an innovative path of development is primarily associated with large-scale investments in human capital. Human development is the main goal and a necessary condition for the progress of modern society. This is our absolute national priority today and in the long term. The future of Russia and our success depend on the education and health of people, on their desire for selfimprovement and the use of their skills and talents..." [3].

The forecast of socio-economic development of the Russian Federation for the period up to 2036, the main strategic directions of human development are defined by the demographic policy, the development of the labour market, income and consumption of the population, the development of education, health, culture, physical culture and sports [4].

As an independent branch of economic analysis, the human capital theory was formed in the second half of the twentieth century, thanks to such researchers as G. Becker, T. Schultz $[5,6]$.

Because of this direction's enormous popularity, many views on this category, there is no single idea of what "human potential" is.

Rimashevskaya M.N., defining human potential as "a special demographic gene pool characterised by an unusual positive specificity", noted that human potential is Russia's main wealth [7]. 
Another point of view is the definition of Zarakovsky G.M., Stepanova G.B., defining human potential is "the ability of society to a productive life in the direction of improving the quality of life of all its members and its stability in the expanding boundaries of internal and external conditions" [8].

Interesting is the point of view of Garifullin E.F., Khannanov T.R., defining human potential as "a set of resources of education, health, work experience and culture of an individual or community as a whole that can be used and implemented by them in the process of political, social, economic and cultural life" [9].

Podberezkin A.I. identified a significant difference between the categories of human capital and human potential. The concept of "human capital", according to the author, is included in the concept of "human potential", since in both cases a person with a certain education, upbringing, preferences and so on is considered. The category of "human capital" refers more to economic activity, while human potential is a more sociological and psychological concept. The author notes that this distinction can also be simplified by linking it with a simple statement: capital is realised potential. The degree of its implementation depends on many reasons. The main reason is the quality of governance of the state and society [10].

\section{EVALUATION METHODS}

To study the human potential quality, the indicator proposed by UNDP - the Human Development Index (HDI) - represented by indicators of health, education and material well-being is most often used [12].

According to the HDI results, Norway has maintained absolute leadership for several decades (refer to table 1). Among the leading countries are Switzerland and
Australia (0.939), respectively, taking second and third places. The Russian Federation had reduced its position from 31st place in 1990 to 49th place in 2018.

The HDI calculation methodology also allows it to be used for calculating human development within a single country, thereby making comparisons of regions within a single country by the level of human development. But the methodology for calculating HDI within a single country is somewhat different from the standard approach. Thus, the HDI of Russia in 2017, calculated according to the standard methodology, was 0.824 , which allowed Russia to be among the countries with a high level of human development, and the HDI, considering the intra-country comparison, was 0.890 in 2017 (refer to table 2).

In 2017, the HDI value in Russia was 0.890 , which is significantly higher than in 2000. The leaders among Russian regions in terms of HDI in 2017 are Moscow, which has held a leading position for decades due to high GRP per capita. The leading position of St. Petersburg is provided by a high level of education, and the Tyumen region-due to the wide coverage of education.

The Jewish Autonomous Region (0.824), the Chechen Republic $(0.807$ - 84th place in the ranking and lagging due to low GRP per capita) and the Republic of Tyva (0.801) retained lagging positions in 2017.

All the North Caucasus Federal District's republics belong to regions with an average level of development of the index. The district's best result was noted in the Republic of North Ossetia-Alania, which occupies the 65th place in the all - Russian rating in 2017.

This article tried to assess human potential development by studying changes in this indicator's educational component.

Table 1. Monitoring of HDI in some countries according to the UNDP methodology [12]

\begin{tabular}{|l|c|c|c|c|c|c|}
\hline \multicolumn{1}{|c|}{ Countries } & 1990 & Rating, 1990 & 2000 & 2010 & 2018 & Rating, 2018 \\
\hline Norway & 0,850 & 3 & 0,917 & 0,942 & 0,954 & 1 \\
\hline Germany & 0,801 & 12 & 0,868 & 0,921 & 0,939 & 4 \\
\hline USA & 0,860 & 2 & 0,885 & 0,914 & 0,920 & 15 \\
\hline Japan & 0,816 & 9 & 0,855 & 0,855 & 0,915 & 19 \\
\hline France & 0,799 & 20 & 0,849 & 0,882 & 0,891 & 26 \\
\hline Poland & 0,712 & 44 & 0,785 & 0,835 & 0,872 & 32 \\
\hline Russia & 0,734 & 31 & 0,720 & 0,780 & 0,824 & 49 \\
\hline Belarus & - & - & 0,683 & 0,792 & 0,817 & 50 \\
\hline China & 0,502 & 102 & 0,594 & 0,706 & 0,758 & 85 \\
\hline
\end{tabular}


Table 2. Human Development Index by regions of Russia [13,14]

\begin{tabular}{|c|c|c|}
\hline Countries & 2000 & 2017 \\
\hline $\mathrm{RF}$ & 0,765 & 0,890 \\
\hline \multirow{5}{*}{$\begin{array}{l}\text { Regions } \\
\text { leaders }\end{array}$} & 1. Moscow (0.864) & 1. Moscow $(0.960)$ \\
\hline & 2. Tyumen region (0.840) & 2. St. Petersburg (0.936) \\
\hline & 3. The Republic of Tatarstan $(0,804)$ & 3. Tyumen region (0.914) \\
\hline & 4. St. Petersburg (0.780) & 4. The Republic of Tatarstan (0.914) \\
\hline & 5. Belgorod region (0.772) & 5. Khanty-Mansiysk Autonomous District-Yugra $(0,911)$ \\
\hline \multirow{4}{*}{\multicolumn{2}{|c|}{$\begin{array}{l}\text { Regions of the North Caucasus Federal District } \\
\text { with an average level of index development }\end{array}$}} & 65. The Republic of North Ossetia-Alania (0.848) \\
\hline & & 66. Stavropol Territory $(0.847)$ \\
\hline & & 67. The Republic of Dagestan (0.844) \\
\hline & & 74. The Republic of Ingushetia (0.833) \\
\hline \multirow{5}{*}{$\begin{array}{l}\text { Regions } \\
\text { outsiders }\end{array}$} & 75. Chukotka AD (0.790) & 81. The Republic of Kabardino-Balkaria (0.826) \\
\hline & 76. Ivanovo region $(0,700)$ & 82. Karachay-Cherkess Republic (0.825) \\
\hline & 77. Chita region (0.698) & 83. The Jewish Autonomous region $(0,824)$ \\
\hline & $\begin{array}{l}\text { 78. The Jewish Autonomous region } \\
(0,697)\end{array}$ & 84. The Chechen Republic $(0,807)$ \\
\hline & 79. The Republic of Tyva (0.633) & 85. The Republic of Tyva $(0,801)$ \\
\hline
\end{tabular}

\section{ASSESSMENT OF HUMAN DEVELOPMENT IN THE NCFD}

\subsection{Analysis of changes in the field of education in 1990-2019 [19]}

The social sphere, the scope and structure of which is extensive in modern developed countries, performs several vital functions, including ensuring human development conditions, a decent quality of life, and society's stability.

The main problem of the modern system of preschool education in all Russia regions is the lack of preschool institutions (table 3). The decline in the country's birth rate in the period 1990-2000 and the subsequent decrease in occupancy and restrictions on financing activities led to reduced the preschool institutions' network. Thus, the number of births per year in the North Caucasus Federal District's republics in 1990-2000 decreased by $43 \%$, and the preschool institutions' network - 32.3\% [20]. The municipalities repurposed the vacant premises of the preschool institutions for other needs. The reduction of the preschool institutions' network in the 1990s and the birth rate increase in the early 2000s led to a shortage of places in the preschool institutions. The period 20102018, though characterised as an increase in the number of preschool institutions, however, the annual growth in the number of children consisting of the account to define in preschool significantly exceed the annual growth of the number of places in preschool institutions, evidence of high tension in this sphere and about the signs of reduced availability of preschool education.

Modern Russia is also characterised by a decrease in the number of general education institutions - schools. This process was especially "landslide" in Russia in 2000-2010, when the number of schools decreased from 68.1 to 49.4 thousand units. In the North Caucasus Federal District regions, this process was particularly acute in 1990-2000: the number of general education institutions decreased by $18.7 \%$. Unfortunately, this trend has continued to this day. Today, the reduction of schools is now under the slogan of optimisation. Its main "victims" were small rural schools.

Since 2010 has seen a counterintuitive situation: the process of increasing students, and along with it a decline in the number of schools (16.4\% in Russia as a whole and $3.1 \%$ - by regions North Caucasus Federal district). All this has led to an increase in the number of children in classes, to an increase in the number of classes, to the appearance of second and even third shifts. The solution to this problem is seen in the construction of small schools in remote mountainous areas and the creation of general education institutions in the format of district boarding schools. 
Table 3. Dynamics of changes in the educational network and the contingent of educational organisations in 1990-2019 [19]

\begin{tabular}{|c|c|c|c|c|c|c|c|c|c|c|c|c|}
\hline & \multicolumn{2}{|c|}{$1990-1991$} & \multicolumn{2}{|c|}{$2000-2001$} & \multicolumn{2}{|c|}{$2010-2011$} & \multicolumn{2}{|c|}{$2015-2016$} & \multicolumn{2}{|c|}{$2018-2019$} & \multicolumn{2}{|c|}{$\begin{array}{r}2018-2019 / \\
2010-2011 \\
\end{array}$} \\
\hline & RF & NCFD & RF & NCFD & RF & NCFD & $\mathrm{RF}$ & NCFD & $\mathrm{RF}$ & NCFD & $\mathrm{RF}$ & NCFD \\
\hline \multicolumn{13}{|c|}{ Preschool education (for the Russian Federation - thousand units; for the North Caucasus Federal District - units) } \\
\hline $\begin{array}{l}\text { Number of } \\
\text { organizations }\end{array}$ & 87,9 & 2945 & 51,3 & 1989 & 45,1 & 2011 & 39,5 & 2244 & 36,6 & 2462 & 81,2 & 123,8 \\
\hline $\begin{array}{l}\text { Number of } \\
\text { pupils, } \\
\text { thousand } \\
\text { people. }\end{array}$ & 9010 & 356 & 4263 & 191 & 5388 & 262 & 7152 & 335 & 7582 & 380 & 140,7 & 199,0 \\
\hline \multicolumn{13}{|c|}{$\begin{array}{l}\text { General education schools (for the Russian Federation - thousand units; for the North Caucasus Federal District - } \\
\text { units) }\end{array}$} \\
\hline $\begin{array}{l}\text { Number of } \\
\text { organizations }\end{array}$ & 69,7 & 3972 & 68,1 & 3230 & 49,4 & 3498 & 42,7 & 3353 & 41,3 & 3388 & 84,6 & 104,9 \\
\hline $\begin{array}{l}\text { Number of } \\
\text { students, } \\
\text { thousand } \\
\text { people }\end{array}$ & 20851 & 1308 & 20493 & 1234 & 13318 & 1124 & 14597 & 11818 & 16137 & 1297 & 121,2 & 105,1 \\
\hline \multicolumn{13}{|c|}{$\begin{array}{c}\text { Secondary vocational education (for the Russian Federation - thousand units; for the North Caucasus Federal } \\
\text { District - units) }\end{array}$} \\
\hline $\begin{array}{l}\text { Number of } \\
\text { organizations }\end{array}$ & 2603 & 96 & 2703 & 100 & 2850 & 122 & 2891 & 150 & 3311 & 215 & 116,2 & 215,0 \\
\hline $\begin{array}{l}\text { Number of } \\
\text { students, } \\
\text { thousand } \\
\text { people. }\end{array}$ & 2270 & 85 & 2361 & 83 & 2126 & 102 & 2180 & 129 & 2464 & 177 & 115,9 & 213,3 \\
\hline \multicolumn{13}{|c|}{ Higher education (for the Russian Federation - thousand units; for the North Caucasus Federal District - units) } \\
\hline $\begin{array}{l}\text { Number of } \\
\text { organizations }\end{array}$ & 514 & 21 & 956 & 60 & 1115 & 65 & 896 & 54 & 741 & 44 & 66,5 & 73,3 \\
\hline $\begin{array}{l}\text { Number of } \\
\text { students, } \\
\text { thousand } \\
\text { people. }\end{array}$ & 2825 & 110 & 4741 & 223 & 7050 & 337 & 4767 & 257 & 4162 & 214 & 59,0 & 96,0 \\
\hline
\end{tabular}

Although the share of persons receiving secondary vocational education in the total population is small compared to the share of students in higher professional education institutions in Russia as a whole, there is an increase in both the number of trainees and the number of organisations providing primary and secondary vocational education.

The situation in the field of dynamics of higher educational institutions is also characterised by inconsistency. At first, their number grew. In the future, due to the absorption of small universities by larger ones, as well as due to the tightening of state policy in this area, the number of organisations began to decrease. The same trend is typical for universities in the North Caucasus. As a result, the total number of people with higher education may decrease in the medium term.

\subsection{Level of education of the economically active population}

Recently, the quality of education has attracted special attention of researchers [15]. The importance of 
the educational component is due to the following factors [16]:

- this is a considerable loss of educational potential associated with the mass emigration of specialists, scientists and skilled personnel.

- information technologies are developing today strengthen the role of knowledge and place high demands on the quality of professional qualifications.

- the severe consequences of socio-economic changes have led to a high degree of differentiation of individual groups and population strata educational potential.

The level of education of the Russian population employed in the economy of the age group 25-64 years, according to the results of the population micro-census in 2015 , is shown in figure 1 . The total number of people employed in the economy is dominated by persons with secondary vocational education in training programs for skilled personnel and employees (34.9\%). The population with higher education accounted for only $30.6 \%$ of the total number of employees.

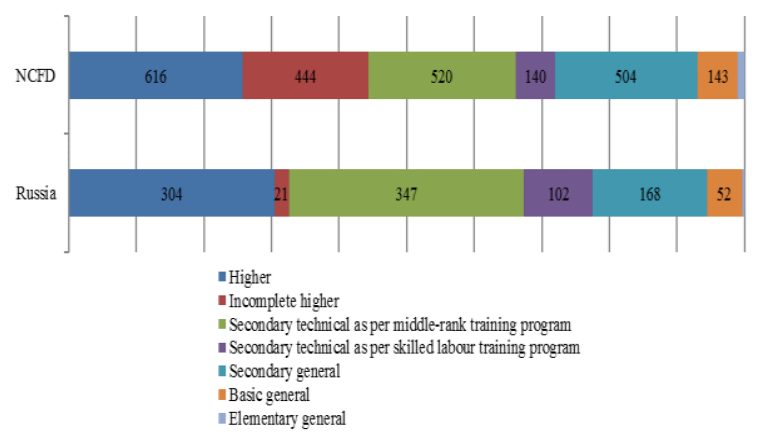

Figure 1 Comparative scheme of the level of education of the economically active population of the Russian Federation and the North Caucasus Federal district aged 25-64 years by age group, took part in the population micro-census in 2015 (per 1 thousand of the population in the relevant age group) [17].

In the context of the North Caucasus Federal District, the structure of education of the employed population aged 25-64 years is dominated by groups of the population with higher education $(30.9 \%$ of the total number of employees) and secondary vocational education in secondary training programs $(26.1 \%)$ and secondary general education $(25.3 \%)$. The share of the population employed in the economy of the NCFD with incomplete higher education is only $2.2 \%$ [18].

\section{RESULTS DISCUSSION}

Speaking about the general situation in education development, it can instead be described as unsatisfactory. This is evidenced by reducing most educational organisations, which cannot be explained only by optimisations and mergers. It should be recognised that this state of education corresponds to the general condition of Russia.

It is hardly possible to make any accurate forecast of the development of the educational system. It depends on the specific actions of the government. One thing is relatively certain - if the current policy is maintained, the process of gradual degradation of the educational sphere will continue. The educational system's main problems remain low academic personnel wages and the deterioration of working conditions (outdated material and technical base) due to the decline in this profession's prestige. One of the main problems of higher professional education is many universities with low quality of educational services and a high degree of duplication of specialities.

Thus, the restructuring of the general education organisations' network was accompanied by a reduction in the number of kindergartens and schools, mainly at the expense of rural areas. Over the period 1990-2018. the network of preschool institutions has decreased in Russia more than 2 times (in the republics of the North Caucasus Federal district -1/3), the network of schools in Russia was reduced in 1,5 times (in the district is somewhat less than $25 \%$ ). Fully restore the network of preschool and school institutions in the period 2000-2018 (when the demand for related services increased again) never succeeded. The discrepancy between educational institutions' system and the existing needs creates difficulties for solving state tasks in demographic policy, creating tension in the social sphere.

\section{CONCLUSION}

The quality of education and its development in the modern world is essential. Education is not only a "market for educational services"; it is also the most important social institution through which the stock of knowledge accumulated by human civilisation is transmitted [21].

The state policy's strategic goal in education is to increase the availability of quality education that meets the requirements of innovative development of the economy, modern needs of society, and every citizen. The implementation of this goal is reflected in several educational development programs and Priority projects.

The implementation of this goal offers solutions to the following priority tasks:

1. Modernisation of educational institutions as instruments of social development, including early development of children regardless of their place of residence, health status, social status; access to quality education for people with disabilities and socialisation.

2. Formation of mechanisms for assessing the quality of demand for educational services with consumers' participation, participation in international comparative 
studies, including consumers and public institutions' involvement in monitoring and evaluating the quality of education.

3. Ensure the innovative nature of primary education under the knowledge-based economy requirements, including updating the content and technologies of education; developing the variability of programs, and updating educational institutions' financing mechanisms.

4. Creation of a modern system of continuous education, training and retraining of professional personnel, support for gifted children. Awards to the winners of Olympiads and creative competitions. The education of talented but poor high school graduates in prestigious Universities. Development of a network of schools for gifted children.

\section{REFERENCES}

[1] E.F. Garifullina, T.R. Khannanova, Development of human potential as a strategic direction of the modern state policy of Russia, Law and Politics 9(153) 2012 1565-1570.

[2] Development of human potential in Russia's regions in the context of the state social policy's strategic goals [Electronic resource]. Retrieved from: http://www.volnc.ru/uploads/activity_files/2018/12 18779.pdf

[3] E.V. Mikhalkina, N.A. Kosolapova, O.Ya. Senkiv, A model for assessing the impact of factors of socioeconomic development of Russian regions on the formation of human potential, Terra economicus 13 2 (2015) 57-72.

[4] Forecast of socio-economic development of the Russian Federation for the period up to 2036 [Electronic resource]. Retrieved from: http://www.economy.gov.ru

[5] G. Becker, Human behaviour, The economic approach, Moscow, 2003.

[6] T. Shultz, Human Capital in the International Encyclopaedia of the Social Sciences, New York, 1968.

[7] N.M. Rimashevskaya, Man and Reforms: secrets of survival, Moscow, 2003, 53 p.

[8] G.M. Zarakovsky, G.B. Stepanova, Population psychological potential: development of the concept, Human potential: the experience of an integrated approach, Moscow, 1999.

[9] E.F. Garifullina, T.R. Khannanova, Development of human potential as a strategic direction of the modern state policy of Russia, Law and Politics 9(153) (2012) 1565-1570.
[10] A.I. Podberezkin, Human capital and its role in the modernisation of Russia, MSIIR Bulletin 5 (2010) 75-100.

[11] M. Simkovic, Risk-Based Student Loans, Washington, 2013.

[12] Data from the official website of the United Nations Development Programme, Human Development Reports, 2020 [Electronic resource]. Retrieved from: http://hdr.undp.org/

[13] Man and innovation, Report on Human Development in the Russian Federation for 2018, Moscow, 2018, $172 \mathrm{p}$

[14] Index of human development of the subjects of the Russian Federation [Electronic resource]. Retrieved from: http://wiki2.org/ru/

[15] N.K. Gabdrakhmanov, N.Yu. Nikiforova, The role of higher education in the spatial polarisation of young people, Economy of the region 154 (2019) 1103-1114.

DOI: https://doi.org/org/10.17059/2019-4-11

[16] O.N. Gorbunova, M.A. Geghamyan, Education as an actual component of human potential, Socioeconomic phenomena and processes 12 (2013) 2528.

[17] Micro Population Census-2015 [Electronic resource].

[18] H.M. Human potential of the North Caucasus regions: state and development, Creative Economy 14(4) (2020) 551-566. DOI: https://doi.org/10.18334/ce.14.4.100770

[19] The Regions of Russia, Socio-economic indicators 2019 [Electronic resource]. Retrieved from: http://rosstat.gov.ru

[20] L.A. Kazarina, E.I. Shabalina, Problems of the functioning of the preschool education system, Baikal Research Journal 2 (2014) 21-27.

[21] V.V. Volchik, E.V. Maslyukova, Reforms, implicit knowledge and institutional traps in education and science, Terra Economicus 17(2) (2019) 146-162. DOI: https://doi.org/10.23683/2073-6606-2019-172-146-162 